\title{
IMPROVING ENGLISH VOCABULARY MASTERY THROUGH LEARNING CIRCUIT MODEL IN ELEMENTARY SCHOOL
}

\author{
Panji Maulana \\ Sekolah Tinggi Ilmu Keguruan dan Pendidikan (STKIP) Sebelas April Sumedang \\ E-mail: panjistkip@gmail.com
}

Submit: 11 Juni 2020, Revisi: 28 Oktober 2020, Approve: 13 November 2020

\begin{abstract}
This study aims to improve students' vocabulary mastery in English subject by using the Circuit Learning Model for fifth grade students of SDN Margalaksana IV . This type of research is Classroom Action Research (CAR) which lasts for two cycles. Each cycle consists of planning, implementing, observing and evaluating actions, then reflecting. The subjects in this study were students in class IV with a total of 27 students. The data in this study were obtained by using data collection techniques of written tests, observations, and oral tests. Based on the result of the research conducted, it showed that the pre-cycle reached an average grade of 45.8 with percentage of classical completeness of $22.2 \%$. In cycle I, the average grade was 66.8 with the percentage of classical completeness of $55.6 \%$. Then in cycle II, the average grade increased up to 85.4 with percentage of classical completeness of $81.5 \%$. The conclusion of this study is that the Circuit Learning Model can improve the mastery of English vocabulary in fifth grade students at SDN Margalaksana IV Cilawu Garut.
\end{abstract}

Keywords: Vocabulary Mastery, English Language, Circuit Learning Model.

Pengutipan: Panji Maulana. (2020). Improving English Vocabulary Mastery Through Learning Circuit Model in Elementary School. JMIE: Journal of Madrasab Ibtidaiyah Education, 4(2), 2020, 283-295. jmie.v4i2.190.

Permalink/DOI: http:/ /dx.doi.org/10.32934/jmie.v4i2.190 


\section{INTRODUCTION}

Today's globalization has unified the world from various aspects, the many exchanges of information between countries through various media are one of the characteristics of globalization and foreign languages are an important part of this information exchange. Mastery of foreign languages is one of the absolute requirements so that Indonesia's young generation not only survive with the existence of other nations in globalization, but also be able to compete with other nations.

English is a foreign language that is used across countries. In the world of education, English is implemented starting from Elementary School (SD) level. At the elementary level, English is used as mulok or an additional subject. This is certainly different from other foreign languages which are rarely provided at the formal education level. There needs to be a habit for students to use English. If students are familiar with and stick to English, the better it is for students to prepare themselves for the upcoming global life.

According to the Education Unit Level Curriculum in Ningrum (2014: 16) English Subjects in SD/MI aim that students have the ability to develop competency in communicating in a limited oral form to accompany action (language accompanying action) in a school context and have an awareness of the nature of and the importance of English in increasing the nation's competitiveness in the global community. Learning English in Primary Schools is deemed necessary, because English is an international language that can support human needs in communicating in this global era.English has four skills which have to be mastered. These four basic skills include listening, speaking, reading, and writing. Before learning these four skills, the main thing students must have vocabulary.

According to Suyanto (2015: 43), "the English vocabulary which needs to be learned by elementary school students in Indonesia is estimated at around 500 words". Based on the results of observations and interviews conducted at SDN Margalaksana IV, there were several problems found by the students, especially most of them have problems in mastering English words, so that they have limited vocabulary in English. Students do not really understand the meaning of words in English, have not been able to listen and speak English words properly, and have not been able to write them in the correct spellings.

Like Indonesian, English has four skills that must be mastered. Four basic skills which include reading, listening, writing and speaking. Perwitasari (2014) states these are four skills are indeed separate from each other, but they are related, and can even be combined with each other. Before learning, students discuss speaking skills, then listen to teacher instructions (listening skills), continue reading (reading skills) and rewrite important information (writing skills).

According to Suyanto (2015: 43), "Vocabulary is a collection of words owned by a language and it gives meaning when we use that language". Meanwhile, according to Purwo in Yulianti (2012: 23), "The mastery of vocabulary is a measure of one's understanding of the vocabulary of a language and their ability to use the vocabulary both spoken and written". Vocabulary is the main asset in communicating both in oral and written form, so vocabulary 
mastery is a must that students need to master. Mastery of vocabulary is a basic ability in language skills, the higher a person's vocabulary knowledge, the more proficient one's language skills are. Vice versa, if someone has a lack of vocabulary, there will be some language barriers.

From all the above theories, it can be concluded that vocabulary is a collection of words possessed by a language. Vocabulary is a very important component and can even be called the key in learning a foreign language since the wealth of one's vocabulary also determines the quality of their language skills (Asnawati 2013). With sufficient vocabulary mastery, communication will occur properly and it can also reduce misunderstandings, especially in communicating by using foreign languages. The mastery of English vocabulary which needs to be learned by elementary school students is estimated at around 500 words. The English mastery indicators can be formulated as follows: (1) Word meaning, (2) Pronunciation, (3) Spelling.

However, based on the results of observations and interviews conducted at elementary schools in Garut Regency, there are several problems including the problems faced by students, namely most students have problems mastering English words so that they have limited vocabulary in English, students do not understand the meaning of English words, not able to listen and pronounce English words well and not able to write them in correct English vocabulary.

With these problems, it is necessary to find alternative solutions to the problem to improve and improve vocabulary mastery in English. Handling these problems requires efforts that aim to improve the learning process in a better direction. One of the efforts that can be made is the application of learning models that refer to the learning process and can aim to improve English vocabulary skills. As stated by Joyce and Weill in Huda (2014: 73), they describe the lesson model as a plan or pattern that can be used to shape curriculum, design instructional materials, and guide the teaching process in the classroom or in different settings.

One of the learning models which can be used to improve vocabulary mastery is the Circuit Learning Model. This is described by Huda (2013: 313). Circuit Learning is a learning model which includes thinking and problem-based approaches in a form of concept maps containing images and writing, so that it becomes meaningful and memorable. According to Joyce \& Weil in Rusman (2014: 133), "Learning model is a plan or pattern which can be used to shape the curriculum (long-term learning plan), design learning materials, and guide learning in the classroom or others".

Huda (2013: 313) stated that, "The advantages of using the Circuit Learning Model are increasing student creativity and training student concentration to focus on the concept map presented by the teacher". During the teaching and learning process, students can observe and pay attention to the materials. This will be more profound and memorable for students since they also experience themselves. The teacher gives students the opportunity to acquire their own knowledge and then arranges it in the form of circuits that can be relearned. By repeating the material independently, it is hoped that students' understanding can last a long time. This model usually starts with visualization and affirmation, questions and answers about the topics studied, presentation of mind maps, explanation of mind maps, division into several groups, 
filling out student worksheets accompanied by mind maps, group presentations and giving rewards.

Based on the opinions of the experts above, Circuit Learning is a learning model that guides students in receiving learning in the form of mind maps by maximizing and seeking empowerment of thoughts and feelings. Circuit Learning learning pattern is carried out by adding (adding) and subtracting (repetition) which is carried out in a conducive and focused learning situation.

The first stage is Visualization and Affirmation. In the visualization step, the teacher invites students to imagine what the students' goals are in learning and how if these goals are achieved. Meanwhile, affirmation in Circuit Learning is done by writing or shouting a short statement that shows enthusiasm and confidence. De Porter stated that the Visualization and Affirmation stage in Circuit Learning aims to break through negative states / thoughts and replace them with empowering thoughts and feelings. The second stage is Making a Mind Map. Tony in De Porter (2014: 225) states that Mind Maps are a creative note-taking method that makes it easy to remember a lot of information. When finished, the notes created will form a pattern of related ideas, with the main topics in the middle and the subopics and breakdown into their branches. A good mind map, according to De Porter, is one that uses colors and uses lots of pictures and symbols. The third stage is Repeating Mind Maps. Mind maps that have been created can be used by students to repeat and study the material again. The repetition process can be done many times until students really understand the material. In addition to repeating, students can also add new information that has not been written on the initial Mind Map. The last stage in Circuit Learning is Re-creating the Mind Map. After the student repeats and adds to the process, students then recreate the Mind Map by rote including the colors, word placements, and symbols from the original Mind Map. According to De Porter, this activity is very helpful in instilling information into the minds of children. After completing a Mind Map, students can compare it to the original Mind Map to see how much information is correct and which areas need attention.

Based on the explanation above, in order that the fifth grade students of SDN Margalaksana IV can improve their vocabulary mastery, the Circuit Learning Model is used in the teaching and learming process. This has encouraged the researchers to get interested in conducting more in-depth study by proposing the title "Improving the Fourth Grade Students' Vocabulary Mastery Through Learning Circuit Model in The English Subject at SDN Margalaksana IV Cilawu Garut ".

\section{METHODS}

The method used in this research is classroom action research (CAR). According to David Hopkins in Tampubolon (2014: 19), classroom action research is a form of strategy in detecting and solving problems faced by educators with concrete actions, namely through research procedures in the form of cycles (recycling). This study aims to determine an improvement in English vocabulary through the Circuit Learning Model in grade IV of SDN 
Margalaksana IV Cilawu Garut. This research was conducted at SDN Margalaksana IV Cilawu Garut, located on Cikancung Street, Cilawu Subdistrict, Garut Regency. The study was conducted research from November 2018 to May 2019.

The subjects in this study were students of class IV SDN Margalaksana IV Cilawu Garut, totaling 27 students, consisting of 14 female students and 13 male students. This research was conducted in 3 cycles. Each cycle consists of 4 stages, namely planning, implementing, observing, and reflecting.

Data collection techniques used were written tests, oral tests and observations. The written test contains 10 short answer questions with a rating scale ranging from 0,1 and 2 . For example $0=$ unable to answer correctly $1=$ less able to answer correctly, $2=$ able to answer correctly. This written test in the form of a short question is based on the theory of vocabulary mastery by Brewster in Ningrum (2014: 32) which includes word meaning, pronunciation, and spelling. The word meaning and spelling sections are used in a short written test, while the part that includes pronunciation uses oral tests. The oral test contains 5 questions with rating scales ranging from 0,1 and 2 . For example $0=$ if aspects of the oral test are carried out with incorrect English pronunciation, 1 = if aspects of the oral test are conducted with a loud voice and improper English pronunciation, 2 = if aspects of the performance are performed with a loud voice and correct English pronunciation.

This research can be declared successful with a single criterion, that is if $75 \%$ of students have vocabulary mastery with the criteria of vocabulary mastery success which falls under excellent category with a range of scores from 80-100.

The implementation of Classroom Action Research is carried out in the form of a cycle or cycle of activities. The design used in this study was a classroom action research designed by Kemmis and Mc'Taggart. According to Tampubolon (2013: 154), the design of classroom action research from Kemmis and McTaggart, each cycle consists of four stages, namely planning, acting, observing, and reflecting, as presented in the following image:

Figure 1. Kemmis and Mc'Taggart's Model PTK Cycle Design Chart 


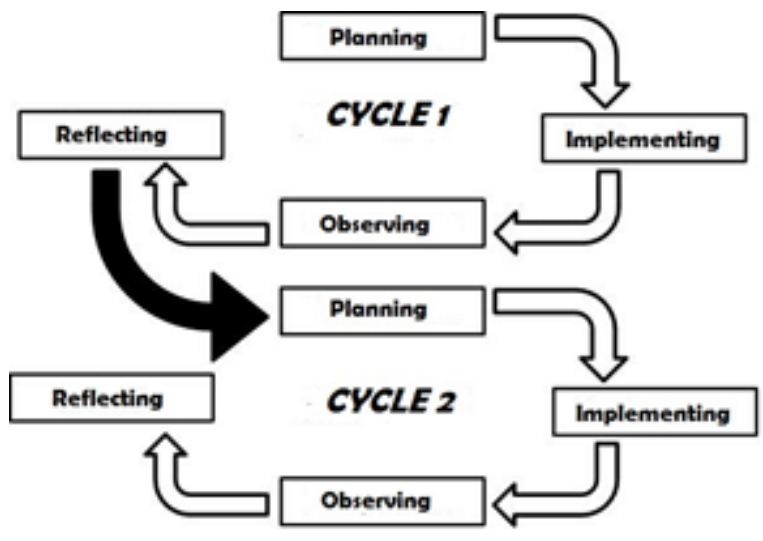

According to Tampubolon (2013: 155), at the planning stage, starting from the process of identifying the problem to be studied, including the results of pre-research, then planning actions to be taken, and compiling learning tools. In this case the researcher uses the Circuit Learning model as determined in order to improve the vocabulary mastery of English for grade IV students at SDN Margalaksana IV. At the implementation stage, it is carried out using learning tools starting from the initial activities, core activities, to the final activities in accordance with the previously made RPP. At the observation stage, learning activities are observed simultaneously (simultaneously when learning takes place). Finally, in the reflection stage, it is an activity to evaluate the results of data analysis about the results of an action taken in order to achieve research success from all the determined indicators.

Data collection techniques according to Sugiyono (2014: 308) are the most important step in research, because the main purpose of research is to get data. Without knowing the data collection technique, the researcher will not get data that meets the established data standards. Data collection techniques in this study include tests and observations, which will be detailed as follows:

\section{The test}

Haris (2012: 67) states that the test is used to measure the extent to which a student has mastered the lessons delivered, especially covering aspects of knowledge and skills. The test in this study used a written test and an oral test which were used to measure students' vocabulary mastery.

\section{Observation}

According to Arifin (2014: 153) observation is a process of systematic, logical, objective, and rational observation and recording of various phenomena, both in actual situations and in artificial situations to achieve certain goals. Observations made in this study were to observe teacher activities while teaching.

\section{RESULTS AND DISCUSSION}


This research starts from Zuchdi's opinion in Meidany (2012: 14) in which Zuchdi understands that vocabulary mastery is one's ability to recognize, understand, and use words properly and correctly by listening, speaking, reading and writing.

Suyanto (2015: 43) argues that vocabulary is a collection of words owned by a language and gives meaning when we use the language. The English vocabulary which needs to be learned by Elementary School students in Indonesia is estimated at around 500 words.

After conducting the action research, the researchers conducted an evaluation to gather information related to the mastery of students' English vocabulary. From the results of the tests carried out in the first cycle, it was found that the total score of students was 1,804 with the average score of 66.8. There were 15 students whose scores exceeded the specified completion criteria with a percentage of classical completeness of 55.6\% and there were 12 students who had not reached the specified completion criteria. The maximum score was 90 and the minimum score was 27.

The completion criteria obtained in the first cycle had not been reached since there were several obstacles encountered, including the following: there were several steps which were not carried out during the research since the researchers were in a hurry; the researchers still could not manage the class well; there were still students who chatted and made the class noisy; when students worked on the worksheet, it was seen that students only relied on one or two of their friends to answer the questions, while the rest of the students were busy chatting, joking and just looking at their friends; on the spelling indicator, there were still many students who spelled the words incorrectly; on the pronunciation indicator, there were many students who were still unable to pronounce correctly; and on the word meaning indicator, there are many students who were still confused about the meaning from Indonesian to English and vice versa.

Implementation of the steps of the Circuit Learning Model consists of three stages, namely:

(1) Stage one is the preparatory stage, (a) Conducting apperception. (b) Explaining the learning objectives that have be achieved by students in the learning activity of that day. (c) Delivering the scope of material and explaining the description of activities.

(2) Stage two is the core activity, (a) Conducting questions and answers about the topics discussed. (b) Posting a picture of the topic on the board. (c) Asking questions about the attached picture. (d) Posting the concept map that has been made. (e) Explaining the attached concept map. (f) Dividing students into groups. (g) Delivering worksheets to each group. (h) Explaining that each group should fill out student worksheets and fill in parts of the concept map with their own language. (i) Explaining that the part of the concept map they are working on will be presented. (j) Presenting the concept map section that has been done. (k) Giving reinforcement in the form of praise or prizes for the results of a good presentation and encouraging those who have not got any praise or prize to try harder. (l) Re-explaining the contents of the student discussion results to strengthen students' insights. 
(3) Stage three is Closing, (a) Stimulating students to make a summary. (b) Assessing students' work.

The solution made for the improvement of cycle I and the plan that will be applied in cycle II are described as follows: the researchers tried to be calm in order to maximize every step in the Circuit Learning Model, researchers and class teachers work together to manage classrooms with seating arrangements using variations that was the style of the team consisting of 5 students on each team and applying the rules of order points that every orderly group would get points, the students with lower cognitive skill were invited to be more active in the learning process such as during the question and answer session, to do the exercises on the worksheet, and during the presentation, to improve the spelling the researchers asked the students to write the spelling and pronounce the spelling correctly, the researchers correct the pronunciation by explaining the correct pronunciation and intonation then directly pointing out the students to know the direct response to the development. After giving an example to the students, the researchers emphasized once more and discussed deeper the indicator which still had low score that is meaning.

After making improvements from the first cycle, the researchers carried out the second cycle and obtained the total score of students was 2,306 with the average score of 85.4. There were 22 students who got the percentage of classical completeness of $81.5 \%$, meaning that they have reached the criteria of success in the vocabulary mastery with excellent category, with a score range of 80-100. However, there were still 5 students who have not reached the specified completeness criteria. The maximum score was 100 and the minimum score was 60 . By making improvements to deficiencies in the first cycle, the implementation of learning in the second cycle improves well and does not require further research.

Overall, students have been able to master the English vocabulary using the Circuit Learning Model. The comparison of students' English vocabulary mastery scores in each cycle can be seen in the following table:

Table 1. The Comparison if Students' English Vocabulary Mastery Scores in Each Cycle

\begin{tabular}{cccc}
\hline Description & Pre-Cycle & Cycle I & Cycle II \\
\hline Total Score & 1237 & 1804 & 2306 \\
\hline Class Average & 45.8 & 66.8 & 85.4 \\
\hline Percentage of Completion $(\%)$ & 22.2 & 55.6 & 81.5 \\
\hline $\begin{array}{c}\text { Total of Students who Reached the } \\
\text { Success Criteria }\end{array}$ & 6 & 15 & 22 \\
\hline Maximum Score & 86 & 90 & 100 \\
\hline Minimum Score & 10 & 27 & 60 \\
\hline Minimum Completion Criteria & & 80 &
\end{tabular}


Further, a graphic presentation of the number of students who achieved the success criteria with excellent categories and the classical completeness percentage from pre-cycle, cycle $\mathrm{I}$ and cycle II is presented below.

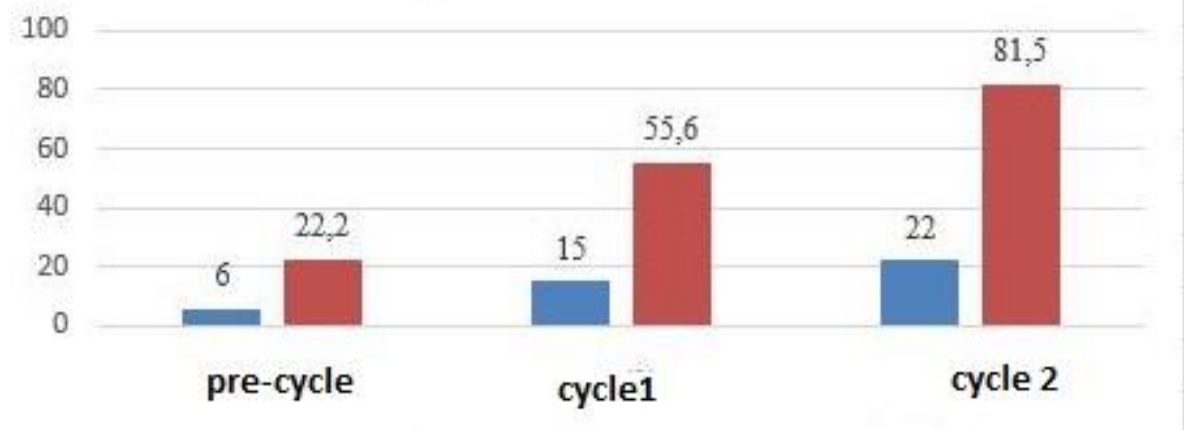

\section{Graph 1. The Number of Students who Achieved Minimum Completion Criteria and Classical Completion Percentage in Each Cycle}

From the graph presented above, it can be concluded that there has been an improvement in each cycle. Percentage of classical students' mastery learning in pre-cycle was $22.2 \%$ with 6 students. After taking the first cycle of action, the percentage of classical learning completeness of students improved by 55.6\% with 15 students, but they had not yet reached the percentage of success criteria of at least $75 \%$. In the second cycle of action, the classical learning completeness of students improved by $81.5 \%$ with 22 students and was completed in accordance with the success criteria of vocabulary mastery with excellent category, with a score range of $80-100$.

The results of the study and the acquisition of evaluation scores in the first and second cycles showed that there was an improvement in English vocabulary through the Circuit Learning Model compared to the state before the research was conducted or pre-research.

\section{a. Discussion}

Learning English by using the Circuit Learning Model can improve English vocabulary as it is seen from the results of the average score and completeness of student learning that has increased in each cycle. According to Brewster in Ningrum (2014: 23), the indicators of English vocabulary mastery are as follows: (1) Word meaning, (2) Pronunciation, (3) Spelling.

Alfin (2019) stated in his research that Circuit Learning is a learning model which is included in the thinking and problem-based approaches in the form of a concept map containing images and writing, so that it becomes meaningful and memorable. According to Huda (2013: 313), the advantages of using the Circuit Learning model are increasing student creativity and training student concentration to focus on the concept map presented by the teacher. During the teaching and learning process, students can observe and pay attention to 
the materials. Therefore, the materials will be more profound and memorable for students since they also experience themselves.

Dewa (2014) has researched about Learning Cycle in Social lesson in elementary school, the results showed that the average score of the resultsobtained after treatment given average at the experimental group students Post Test of 79.30 and 73.72 were the control group then the data were analyzed by using t-test statistic is obtained $\mathrm{t}(3.72)$ with significance level $\alpha=5 \%$ is obtained t table (2.00). Because $\mathrm{t}>\mathrm{t}$ table means that Ho is rejected and $\mathrm{Ha}$ accepted. So it can be conclude that circuit learning model assisted by audio visual media givesignifi cant differences toward the student's achievement is learning social (IPS). It is recommended that the circuit learning model can be used as an alternative in learning social studies in elementary school

The use of the circuit learning model has previously been used by another researcher Nancy (2017), whose results have been able to show the implementation of the Circuit Learning model in learning ecosystem themes, the learning outcomes of class $\mathrm{V}$ students on the ecosystem theme after applying the model Circuit Learning, and the influence of the Circuit Learning model on learning outcomes for the theme of ecosystems for fifth grade students. The method used is Quasi Experimental Nonequivalent Control Group Design. The results showed that the learning implementation using the Circuit Learning model reached 100\%. The results of learning knowledge are indicated by the posttest average of the experimental class, namely 85.42 and the average gain score of 31.39. The average posttest control class was 74.17 and the average gain score was 21.81 . The average learning outcomes of the experimental class skills in learning 1 and 2 were 85.17 and 82.42. This value is higher than the control class average of 78.78 and 73.22 . In the attitude dimension, the average learning outcomes of the experimental class in learning 1 and 2 were 84.47 and 82.47. This value is higher than the average learning outcomes of the control class of 78.58 and 76.19 . It can be concluded that the learning outcomes of the experimental class that apply the Circuit Learning model are better than those of the control class who apply the direct learning model.

There are some differences in the data of cycle I and cycle II, namely, the maximum score was 90, then after the action in cycle II , it became 100. Meanwhile, the minimum score obtained in cycle I was only 27 , but after the action in cycle II, it increased to 60 . Then, it can be seen that the total scores obtained by students in the first cycle was 1,804 , but after the action in cycle II, it increased to 2,306. Furthermore, for the average score of the class during the first cycle was 66.8 , but after taking action in the second cycle, it increased to 85.4. Then the number of students who completed in the first cycle was 15 students with a percentage of classical completeness of $55.6 \%$, while after taking action on the second cycle students who completed were as many as 22 students with a percentage of $81.5 \%$. The ability of mastering English vocabulary obtained by students does not all reach the expected score since there are still 5 students whose scores are below the excellent criteria for success categories of 80-100.

Yodisudana (2013) stated in his research that Circuit Learning Model is one of the learning models included in the thinking and problem-based approach that has a complete component in creating an active, innovative, creative and fun learning atmosphere with the aim of maximizing the empowerment of thoughts and feelings with increasing patterns and repeat. 
It can be concluded that in this study, there was "an improvement in English vocabulary by using the Circuit Learning Model in grade IV of SDN Margalaksana IV ". This is evidenced by the increased completeness of student learning at each cycle and the achievement of the researchers' pre-determined indicators at the beginning of the study.

\section{CONCLUSION}

Based on the results of Classroom Action Research (CAR) that have been conducted at SDN Margalaksana IV , in the English subject by using the Circuit Learning Model, it can be concluded that in the first cycle of action research obtained an average score of 66.8 with the acquisition of the percentage of classical completeness by $55.6 \%$. And in the second cycle, the average score is 85.4 with the acquisition of the percentage of classical completeness of $81.5 \%$. This indicates that there is an improvement in vocabulary mastery for students.

\section{REFERENCES}

\section{Book}

Arifin, Z. (2014). Evaluasi Pembelajaran Prinsip, Teknik, Prosedur. Bandung: PT Remaja Rosdakarya. Dewi, Dewa Ayu Puspa. (2013). Pengarub Model Pembelajaran Circuit Learning Berbantuan Media Audiovisual Terhadap Hasil Belajar IPS Siswa SD Negeri 1 Pejeng. Universitas Ganesha.

De Porter. (2014). Quantum Teaching. (terj.Ali Nilandari), Bandung : Kaifa, 2014.

Haris, Herdiansyah. (2012). Metode Penelitian Kualitatif untuk Ilmu-ilmu Sosial. Jakarta: Salemba Humanika.

Huda, M. (2014). Model-Model Pengajaran dan Pembelajaran. Yogyakarta: Pustaka Pelajar.

Huda, Miftahul. (2013). Model-model Pengajaran dan Pembelajaran. Yogyakarta: Pustaka Pelajar.

Joyce, Bruce and Weil, Marsha. (1980). Models of Teaching (Second Edition). Englewood Cliffs, New Jersey: Prentice-Hall, Inc.

Ningrum, Perwitasari. (2014). Peningkatan Penguasaan Kosakata Bahasa Inggris Materi Family Melalui Lagu Pada Siswa Kelas V SD N Piyaman II, Wonosari. Skripsi. PGSD FIP. Universitas Negeri Yogyakarta.

Sugiyono. (2014). Metode Penelitian Pendidikan Pendekatan Kuantitatif Kualitatif dan R\&D. Alfabeta: Bandung.

Suyanto, Kasihani K. E. (2015). English for Young Learners. Jakarta: Bumi Aksara.

Tampubolon. (1993). Mengembangkan Minat dan Kebiasaan Membaca Pada Anak. Bandung: Angkasa.

Tampubolon, S. M. (2013). Penelitian Tindakan Kelas Untuk Pengembangan Profesi Pendidik dan Keilmuan. Jakarta: Erlangga. 
Yodisudana, Yeyen. (2013). Peningkatan Hasil Belajar IPS Menggunakan Model Pembelajaran Circuit Learning Kelas V SDN II Bandung. Universitas Tulung Agung.

Zuchdi, Darmiyati. (2008). Strategi Meningkatkan Kemampuan Membaca Peningkatan Komprehensi. Yogyakarta: UNY Press.

\section{Journal/Thesis/Dissertation}

Alfin, Muhammad Babun. (2019). Analisis Kemampuan Berpikir Kritis Siswa Terhadap Pembelajaran Hypothetico-Deductive Reasoning Dalam Learning Cycle $7 e$. https://journal.unesa.ac.id/index.php/jppipa/article/view/7436. (Retrieved on Friday, $6^{\text {th }}$ of November 2020 at 13.13 P.M.)

Asnawati, A. S. (2013). Korelasi Antara Penguasaan Kosakata Aktif-Produktif. Jurnal Pendidikan dan Pembelajaran (JIPP). Vol 2 No 12.

Dewa, dkk. (2014). Pengaruh Model Pembelajaran Circuit Learning Berbantuan Media Audiovisual terhadap Hasil Belajar Siswa SD N 1 PejejengTahun Pelajaran 2013/2014. Jurnal Mimbar PGSD Universitas Pendidikan Ganesha.

Meidany, C. (2012). Kontribusi Penguasaan Kosakata Dan Motivasi Belajar Terhadap Kemampuan Membaca Teks Berbahasa Jerman Peserta Didik Kelas XI Program Keablian Animasi SMK Negeri 5 Yogyakarta Tahun Ajaran 2011/2012. http://eprints.uny.ac.id/9123/1/108203244001.pdf. (Retrieved on Saturday, 14th of October 2017 at 10.06 P.M.).

Nancy Adriana Lalawi, Soeparman Kardi, Tjipto Prastowo. (2017).Pengembangan Perangkat Pembelajaran Berbasis 5 e Learning Cycle Pada Pokok Bahasan Energi Untuk. Meningkatkan Hasil Belajar Siswa Sekolah Menengab Pertama. https://journal.unnes.ac.id/nju/index.php/JPP/article/view/9615 2017. (Retrieved on Friday, $6^{\text {th }}$ of November 2020 at 13.13 P.M.)

Perwitasari, Ningrum. (2014). Peningkatan Penguasaan Kosakata Bahasa Inggris Materi Family Melalui Lagu Pada Siswa Kelas $V$ SDN Piyaman II Wonosari. http:/ / eprints.uny.ac.id/14041/1/SKRIPSI\%20Ningrum\%20Perwitasari.pdf. (Retrieved on Wednesday, 27 th of September 2017 at 10.15 P.M.). 